\title{
IMPROVING TOLERANCE OF CORTADERIA SELLOANA PLANTS TO IRRIGATION WATER SALINITY THROUGH SALICYLIC ACID APPLICATION
}

\author{
M.A. El-Ashwah \\ Ornamental Plants and Landscape Gardening Res. Dept., Hort. Res. Inst., ARC, Egypt
}

\begin{abstract}
In order to improve the ability of the Cortaderia selloana (pampas grass) seedlings to withstand the salinity of irrigation water, a pot experiment was conducted at the Experimental Farm of Ornamental Plants and Landscape Gardening, Res. Dept., Hort. Res. Inst., ARC, Giza, Egypt during 2017/2018 and 2018/2019 seasons. Seedlings were irrigated with a saline water containing $\mathrm{NaCl}$ at concentrations of $0,6000,8000$ and $10000 \mathrm{ppm}$ and sprayed with salicylic acid (SA) at concentrations of 0, 50, 100 and $150 \mathrm{ppm}$. The results showed that irrigation with saline water led to a remarkable gradual decrease in all vegetative, flowering and root characteristics as well as the contents of total carbohydrates and chlorophylls with increasing salinity levels, this was accompanied with more accumulation of proline, sodium and chlorine in leaves. Regarding foliar spraying with SA, there was an increment in vegetative, floral and root characteristics due to increasing SA concentrations until reaching the maximum growth rate at a concentration of $150 \mathrm{ppm}$, and it also increased the leaf content of total carbohydrates, total chlorophylls and proline. On the other hand, SA reduced the accumulation of sodium and chlorine in the leaves. The interaction between SA and saline water treatments cleared that SA application ameliorated the adverse effects of salinity on shoots, flowers and root growth. The best results were obtained with SA at $150 \mathrm{ppm}$ for plants under a salinity of $6000 \mathrm{ppm}$, where this interaction achieved the best vegetative and floral growth equal or better than control in most cases. Accordingly, it may be recommended to spray Cortaderia selloana with a solution of SA at a rate of $150 \mathrm{ppm}$ once every three weeks to obtain good growth under salinity stress of water up to $6000 \mathrm{ppm}$ conditions.
\end{abstract}

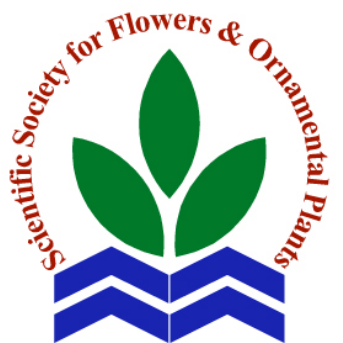

Scientific J. Flowers \& Ornamental Plants, 7(3):349-361 (2020).

Received: 25/8/2020

Accepted: $14 / 9 / 2020$

Key words: Cortaderia selloana, pampas grass, $\mathrm{NaCl}$, saline water, salicylic acid.

\section{INTRODUCTION}

Cortaderia selloana (Schult. \& Schult.f.) Asch. \& Graebn. (Fam: Poaceae) is an evergreen plant native to South America and New Zealand, large, densely tufted, perennial grass, the common name is pampas grass, forming large clumps, $1.8-3.7 \mathrm{~m}$ high, the lower internodes is short and the upper one is very long. Foliage medium to glaucous green, medium in texture, mostly crowded at the base of the culm; upper leaves 0.3-2.5 m long, Staminate inflorescence are branched, oblong, panicle 60-70 cm long, about 20-30 $\mathrm{cm}$ wide, the branches is erect or ascending and spreading, bearing spikelets nearly to the base, the inflorescence is usually white, beige or offwhite. Flowering and fruiting occur from early June until frost in the native area. Cortaderia selloana can used in lawns, in 
rock and water gardens, and around swimming pools and patios; it acts as a screen along driveways and property lines. Cortaderia selloana is excellent sources of cut flowers when the inflorescence has attained its maximum size and brilliance in color and the mature panicles are useful in dried arrangements (Oakes, 1990).

Salinity causes flowering delay and leaf chlorosis, a reduction in shoot and root growth; and bulb production. This was documented by El-Fouly et al. (2015) on Iris tingitana cv. Wedgewood, Oliveira et al. (2017) on Catharanthus roseus, Allamanda cathartica, Ixora coccinea and Duranta erecta; in addition to Bian and Pan (2018) on Narcissus tazzeta var. chinensis, Hassan and Abd El-Azeim (2019) on Polianthes tuberosa and Hoang et al. (2020) on Amaranthus tricolor.

Under salt stress, plants produce some signaling molecules, which can reduce deleterious effects. One of these signaling compounds, salicylic acid (SA) is known to improve plant adaptations to stressful conditions (Dempsey and Klessig, 2017 and Kudla, 2018). SA as a phytohormone, affects plant growth processes, from seed germination to yield (Dempsey and Klessig, 2017), and improves a plant's tolerance against both biotic and abiotic stresses, including salinity (Tissa et al., 2000 and AlWhaibi et al., 2012). Exogenous applied SA has been reported to improve salinity tolerance by enhancing membrane stability and photosynthetic rates in barley (El-Tayeb, 2005; Al-Whaibi et al., 2012).

This study was conducted to evaluate the effect of irrigation water salinity on growth, plant chemical constituents and quality of Cortaderia selloana as a garden plants and to increase the ability of the plant to withstand high levels of saline water by applying different levels of salicylic acid.

\section{MATERIALS AND METHODS}

A trial was performed under open field conditions at the Experimental Farm of Ornamental Plants and Landscape Gardening, Res. Dept., Hort. Res. Inst., ARC, Giza, Egypt through 2017/2018 and 2018/2019 seasons to investigate the effect of salicylic acid on the performance of Cortaderia selloana under saline water irrigation.

Transplants of Cortaderia selloana (one tiller, 90-100 cm height with 16-18 leaves) were obtained from local nursery in AlQanatir Al-Khayriyyah, Qalyubia Governorate.

The transplants were immediately planted on July $15^{\text {th }}$ in both seasons in $30-\mathrm{cm}$ diameter plastic pots filled with about 5.5 $\mathrm{kg} /$ pot of the loamy soil. Physical and chemical properties of the field soil are shown in Table (a).

\section{Treatments:}

The seedlings were irrigated with fresh water once every three days for 30 days till mid of August, then they were received the following treatments:

1. Saline water treatments: pure $\mathrm{NaCl}$ salt was used to prepare artificial saline water at concentrations of $0,6000,8000$, and $10000 \mathrm{ppm}$. The seedlings were irrigated with the previous saline water every three days until the experiment was terminated 14 months later (on October $15^{\text {th }}$ ).

2. Salicylic acid was applied as foliar spraying at $0,50,100$ and 150 ppm every 3 weeks.

3. These salicylic acid treatments were combined with those of saline water to create 16 interaction treatments.

Table a. The physical and chemical analyses of the used soil.

\begin{tabular}{|c|c|c|c|c|c|c|c|c|c|c|c|c|c|}
\hline \multirow{2}{*}{ Soil type } & \multicolumn{3}{|c|}{$\begin{array}{c}\text { Particle size } \\
\text { distribution (\%) }\end{array}$} & \multirow{2}{*}{ S.P. } & \multirow{2}{*}{$\begin{array}{c}\text { E.C. } \\
(\mathrm{dS} / \mathrm{m})\end{array}$} & \multirow{2}{*}{$\mathbf{p H}$} & \multicolumn{4}{|c|}{ Cations (meq/l) } & \multicolumn{3}{|c|}{ Anions (meq/l) } \\
\hline & Sand & Silt & Clay & & & & $\mathrm{Ca}^{++}$ & $\mathbf{M g}^{++}$ & $\mathrm{Na}^{+}$ & $\mathbf{K}^{+}$ & $\mathrm{HCO}_{3}$ & $\mathrm{Cl}^{-}$ & $\mathrm{SO}_{4}^{--}$ \\
\hline Loamy & 48.0 & 35.5 & 16.5 & 44.0 & 1.36 & 8.28 & 3.5 & 2.5 & 6.63 & 0.65 & 0.5 & 7.5 & 5.28 \\
\hline
\end{tabular}


A factorial experiment based on a complete randomized block design, replicated thrice with 4 plants per replicate was accomplished in both seasons according to Gomez and Gomez (1984).

The plants under various treatments were fertilized every two weeks with 2 g/pot of commercial chemical fertilizer "Flowering Spring” produced by Agrico International Co., containing 20 N : $20 \mathrm{P}: 20 \mathrm{~K}+$ micronutrients and the other agricultural practices were undertaken whenever needed, as usually grower did.

\section{Data recorded:}

\section{Vegetative growth parameters:}

Plant height $(\mathrm{cm})$ (average length of tillers), average number of leaves/tiller, number of tillers/plant, vegetative fresh and dry weights (average tillers fresh and dry weights), roots fresh and dry weights and foliar salt damage and plant growth. A Reference scale (visual score) from 0 to 5 according to Sun et al. (2015).

\section{Flowering specifications:}

Number of days till flowering, number of inflorescences/plant, spike length (from pot surface to end of the inflorescence (m), spike weight (g) and diameter of the inflorescence $(\mathrm{cm})$ at $15 \mathrm{~cm}$ from the base of the inflorescence.

\section{Chemical composition:}

At the end of the second season, chemical composition analysis was carried out as following:

1. Total carbohydrates (\% in dry matter) according to Dubois et al. (1956).

2. Photosynthetic pigments (total chlorophylls $(a+b) ; m g / g$ f.w.): fresh leaves were collected from all plots to determine total chlorophyll content, according to the method described by Wellburn and Lichtenthaler (1984).

3. Sodium and chloride contents (mg/g d.w.) were determined using the methods of Jackson (1973). Free proline content was colorimetrically evaluated in dry leaf samples according to Bates et al. (1973).

\section{Statistical analysis:}

All obtained data were statistically analyzed according to the technique of analysis of variance (ANOVA) for a complete randomized block design in a factorial experiment as published by Gomez and Gomez (1984) by using "MSTAT-C" computer software package (MSTAT Development Team, 1989). Means of treatments were compared using Duncan's multiple range tests at 5\% level of probability as described by Duncan (1955).

\section{RESULTS}

Effect of salinity levels, salicylic acid (SA) rates and their interactions on:

\section{Vegetative growth parameters:}

Concerning the effect of salinity of irrigation water, data in Table (1) show that treated plants were affected significantly by salinity of irrigation water. Increasing saline doses led to a gradual decrease in all characteristics of plant growth, as Plant height, number of tillers/plant and number of leaves/tiller were decreased progressively with increasing the salinity level. The least values occurred at the highest level (10000 ppm), compared to plants irrigated with nonsaline water (2.66 and $2.50 \mathrm{~m}$ for plant height, 17.87 and 16.91 for number of tillers/plant and 35.17 and 35.63 for number of leaves/tiller, in both seasons, respectively).

As for the effect of SA application, the same data in Table (1) indicated that increasing in all data to the maximum values as a result of increasing SA dose to by the highest dose (150 ppm), the highest values were (2.22 and $2.10 \mathrm{~m}$ for plant height, 15.91 and 14.85 for number of tillers and 29.0 and 30.53 for number of leaves/tiller in the $1^{\text {st }}$ and $2^{\text {nd }}$ seasons respectively).

The interactions between salinity of irrigation water and SA treatments also exerted a marked effect, where the plants received SA at either 50, 100 or $150 \mathrm{ppm}$ 
Table 1. Effect of saline water, salicylic acid and their interaction on plant height, number of tillers/plant and number of leaves/tiller of Cortaderia selloana plants during 2017/2018 and 2018/2019 seasons.

\begin{tabular}{|c|c|c|c|c|c|c|c|c|c|c|}
\hline \multirow{3}{*}{$\begin{array}{l}\text { Water salinity } \\
\text { levels (ppm) }\end{array}$} & \multicolumn{10}{|c|}{ Salicylic acid (ppm) } \\
\hline & $\begin{array}{c}\text { Control } \\
\text { (0) }\end{array}$ & 50 & 100 & 150 & $\begin{array}{l}\text { Mean } \\
\text { (A) }\end{array}$ & $\begin{array}{c}\text { Control } \\
\text { (0) }\end{array}$ & 50 & 100 & 150 & $\begin{array}{c}\text { Mean } \\
\text { (A) }\end{array}$ \\
\hline & \multicolumn{4}{|c|}{$2017 / 2018$} & & \multicolumn{5}{|c|}{ 2018/2019 } \\
\hline & \multicolumn{10}{|c|}{ Plant height (m) } \\
\hline Control (0) & $2.59 \mathrm{c}$ & $2.57 \mathrm{c}$ & $2.73 \mathrm{~b}$ & $2.76 \mathrm{a}$ & $2.66 \mathrm{a}$ & $2.36 \mathrm{~d}$ & $2.40 \mathrm{c}$ & $2.59 \mathrm{~b}$ & 2.65 a & $2.50 \mathrm{a}$ \\
\hline 6000 & $2.02 \mathrm{~g}$ & $2.17 \mathrm{f}$ & $2.34 \mathrm{e}$ & $2.52 \mathrm{~d}$ & $2.26 \mathrm{~b}$ & $1.92 \mathrm{~g}$ & $2.00 \mathrm{f}$ & $2.18 \mathrm{e}$ & $2.40 \mathrm{c}$ & $2.13 \mathrm{~b}$ \\
\hline 8000 & $1.79 \mathrm{j}$ & $1.86 \mathrm{i}$ & $1.91 \mathrm{~h}$ & $1.89 \mathrm{~h}$ & $1.86 \mathrm{c}$ & $1.50 \mathrm{k}$ & $1.60 \mathrm{j}$ & $1.75 \mathrm{~h}$ & $1.75 \mathrm{~h}$ & $1.65 \mathrm{c}$ \\
\hline 10000 & $1.64 \mathrm{~m}$ & $1.61 \mathrm{l}$ & $1.70 \mathrm{k}$ & $1.70 \mathrm{k}$ & $1.67 \mathrm{~d}$ & $1.44 \mathrm{l}$ & $1.43 \mathrm{l}$ & $1.64 \mathrm{i}$ & $1.58 \mathrm{j}$ & $1.53 \mathrm{~d}$ \\
\hline \multirow[t]{2}{*}{ Mean (B) } & $2.01 \mathrm{~d}$ & $2.05 \mathrm{c}$ & $2.17 \mathrm{~b}$ & $2.22 \mathrm{a}$ & & $1.81 \mathrm{~d}$ & $1.86 \mathrm{c}$ & $2.04 \mathrm{~b}$ & $2.10 \mathrm{a}$ & \\
\hline & \multicolumn{10}{|c|}{ Number of tillers/plant } \\
\hline Control (0) & 17.67 a & $16.33 \mathrm{bc}$ & 18.63 a & $18.83 \mathrm{a}$ & $17.87 \mathrm{a}$ & $15.33 \mathrm{~cd}$ & $15.83 \mathrm{bc}$ & $17.13 \mathrm{~b}$ & 19.33 a & $16.91 \mathrm{a}$ \\
\hline 6000 & $12.87 \mathrm{f}$ & $12.97 \mathrm{ef}$ & 14.43 de & $17.83 \mathrm{a}$ & $14.53 \mathrm{~b}$ & $13.17 \mathrm{e}$ & $13.43 \mathrm{e}$ & 14.20 de & $15.37 \mathrm{~cd}$ & $14.04 \mathrm{~b}$ \\
\hline 8000 & 9.43 hi & $10.53 \mathrm{gh}$ & $11.67 \mathrm{fg}$ & $14.87 \mathrm{~cd}$ & $11.63 \mathrm{c}$ & $8.20 \mathrm{~g}$ & $11.63 \mathrm{f}$ & $10.77 \mathrm{f}$ & $13.83 \mathrm{e}$ & $11.11 \mathrm{c}$ \\
\hline 10000 & $6.43 \mathrm{j}$ & $5.87 \mathrm{j}$ & $8.20 \mathrm{i}$ & $12.10 \mathrm{f}$ & $8.15 \mathrm{~d}$ & $5.53 \mathrm{~h}$ & $6.00 \mathrm{~h}$ & $7.50 \mathrm{~g}$ & $10.87 \mathrm{f}$ & $7.48 \mathrm{~d}$ \\
\hline \multirow[t]{2}{*}{ Mean (B) } & $11.6 \mathrm{c}$ & $11.42 \mathrm{c}$ & $13.23 \mathrm{~b}$ & $15.91 \mathrm{a}$ & & $10.56 \mathrm{~d}$ & $11.73 \mathrm{c}$ & $12.4 \mathrm{~b}$ & $14.85 \mathrm{a}$ & \\
\hline & \multicolumn{10}{|c|}{ Number of leaves/tiller } \\
\hline Control (0) & $35.33 \mathrm{ab}$ & $34.33 \mathrm{c}$ & $35.00 \mathrm{ab}$ & $36.00 \mathrm{a}$ & 35.17 a & $35.00 \mathrm{bc}$ & $34.67 \mathrm{c}$ & 35.33 bc & $37.50 \mathrm{a}$ & $35.63 \mathrm{a}$ \\
\hline 6000 & $27.33 \mathrm{~d}$ & $25.33 \mathrm{e}$ & $26.67 \mathrm{~d}$ & $35.17 \mathrm{ab}$ & $28.63 \mathrm{~b}$ & $24.00 \mathrm{gh}$ & 25.00 ef & $26.17 \mathrm{~d}$ & $35.61 \mathrm{~b}$ & $27.70 \mathrm{~b}$ \\
\hline 8000 & $21.00 \mathrm{~h}$ & $21.00 \mathrm{~h}$ & $22.33 \mathrm{~g}$ & $23.67 \mathrm{f}$ & $22.00 \mathrm{c}$ & $20.00 \mathrm{j}$ & $22.17 \mathrm{i}$ & $24.50 \mathrm{fg}$ & $25.33 \mathrm{e}$ & $23.00 \mathrm{c}$ \\
\hline 10000 & $20.00 \mathrm{i}$ & 20.67 hi & 20.67 hi & $21.33 \mathrm{~h}$ & $20.67 \mathrm{~d}$ & $17.67 \mathrm{k}$ & $20.33 \mathrm{j}$ & $22.67 \mathrm{i}$ & $23.67 \mathrm{~h}$ & $21.08 \mathrm{~d}$ \\
\hline Mean (B) & $25.92 b$ & $25.33 \mathrm{c}$ & $26.17 \mathrm{~b}$ & $29.00 \mathrm{a}$ & & $24.17 \mathrm{~d}$ & 25.54 c & $27.17 \mathrm{~b}$ & $30.53 \mathrm{a}$ & \\
\hline
\end{tabular}

Means having the same letter are not significantly differed at 0.05 level of probability according to Duncan's Multiple Range Test (Duncan, 1955).

and irrigated with non-saline water recorded, the utmost high values in the two seasons, with the superiority of the combined treatment of fresh water + SA at $150 \mathrm{ppm}$, as it gave the highest records (2.76 and $2.65 \mathrm{~m}$ for plant height, 18.83 and 19.33 for number of tillers/plant and 36.0 and 37.5 for number of leaves/tiller in the $1^{\text {st }}$ and $2^{\text {nd }}$ seasons, respectively). Generally, the gradual increment in salinity of irrigation water was accompanied by a progressive suppress in all measurements and this impact which was improved by the gradual increase in SA dose.

Data in Table (2) show that treating plants with high levels of salinity showed marked decrease in fresh and dry weights of shoot and root growth. The best values were (197.8 and $209.5 \mathrm{~g}$ for vegetative fresh weight, 58.7 and $60.9 \mathrm{~g}$ for vegetative dry weight, 1.353 and $1.418 \mathrm{~kg}$ for root fresh weight and 0.476 and $0.500 \mathrm{~kg}$ for root dry fresh weight in both seasons, respectively) for the plants irrigated with tap water (control).

Concerning the effect of SA application (Table, 2) it was found that treating plants with higher levels of SA showed increases in the fresh and dry weights of shoot and root growth. Moreover, treating plants with SA at $150 \mathrm{ppm}$ achieved the highest values (174.3 and $184.6 \mathrm{~g}$ for vegetative fresh weight, 46.4 and $52.7 \mathrm{~g}$ for vegetative dry weight, 1.095 and $1.146 \mathrm{~kg}$ for root fresh weight and 0.315 and $0.344 \mathrm{~kg}$ for root dry weight in the $1^{\text {st }}$ and $2^{\text {nd }}$ seasons, respectively.

Regarding the effect of the interaction, the recorded data show that SA at $150 \mathrm{ppm}$ combined with non-saline water was the best treatment for enhancing plant fresh and dry weight for shoot and root growth in both seasons. The values were (218.3 and 231.7 for vegetative fresh weight/tiller, 68.3 and 
Table 2. Effect of saline water, salicylic acid and their interaction on vegetative fresh and dry weights, root fresh and dry weights of Cortaderia selloana plants during 2017/2018 and 2018/2019 seasons.



Means having the same letter are not significantly differed at 0.05 level of probability according to Duncan's Multiple Range Test (Duncan, 1955).

$76.9 \mathrm{~g}$ for vegetative dry weight/tiller, 1.563 and $1.602 \mathrm{~kg}$ for root fresh weight/plant and 0.563 and $0.577 \mathrm{~kg}$ for dry root weight/plant in the first and second seasons, respectively. It can also be observed that treating plants with SA could improve the fresh and dry weights of vegetative and roots in plants received saline water.

\section{Visual score:}

Referring to Fig. (1), salinity levels decreased the quality of Cortaderia plants to the minimum score (3.8) when irrigated with saline water at $10000 \mathrm{ppm}$.

On the other hand, the visual score of plants increased by increasing the concentration of salicylic acid which, reached to maximum score (4.6) for plants treated with SA at $150 \mathrm{ppm}$.

Regarding to the interaction between salinity and SA foliar application, it was found that spraying plants with SA increased plant quality grown under all saline concentrations, reaching to excellent visual score (5.0) in plants received saline irrigated water at $6000 \mathrm{ppm}$ and SA at $150 \mathrm{ppm}$.

Although salinity stress concentrations correlated negatively with visual score, Cortaderia still exhibited a good visual quality. These results indicate that leaf $\mathrm{Na}^{+}$ and $\mathrm{Cl}^{-}$concentrations are still not high 


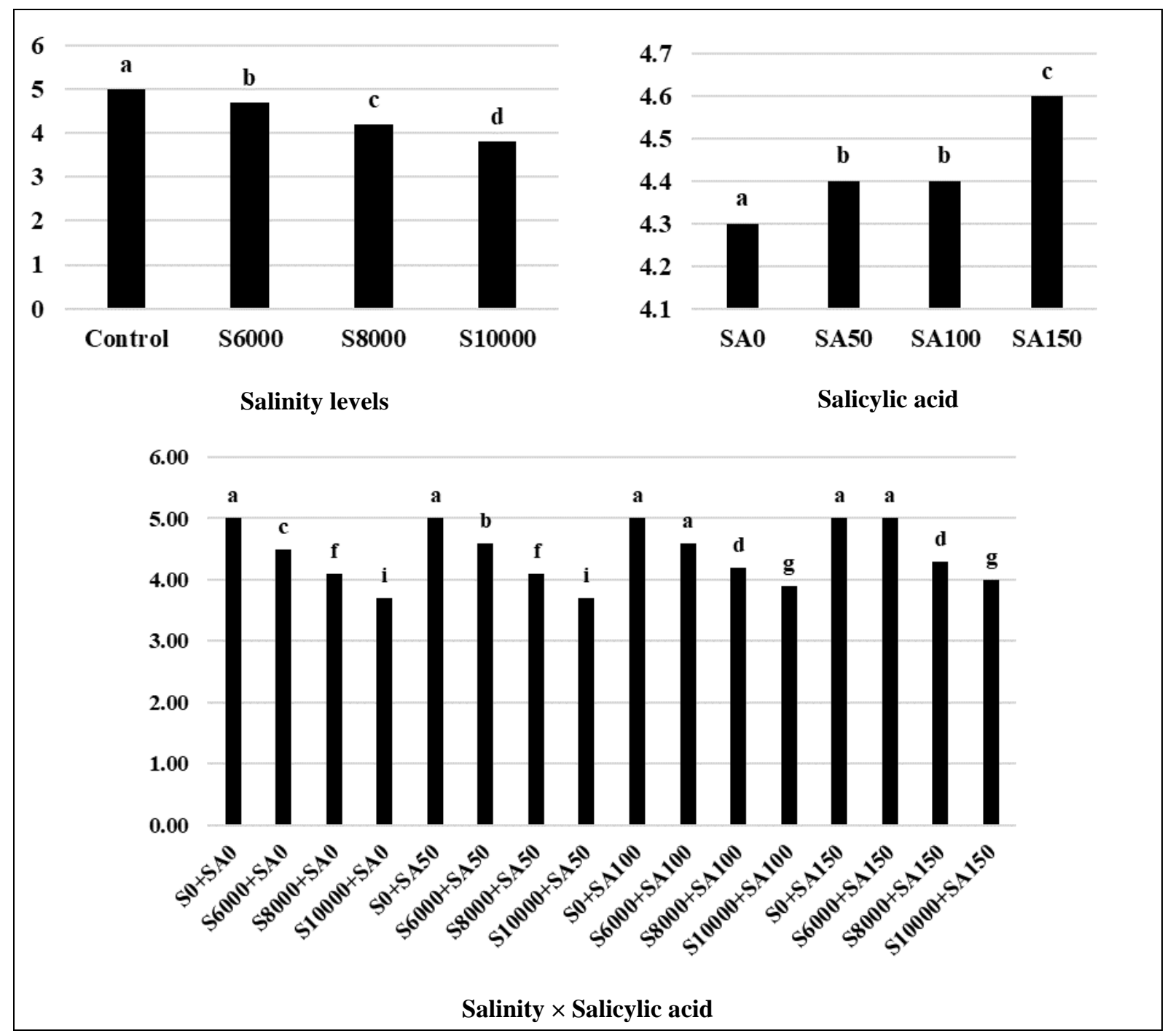

Fig. 1. Effect of saline water, salicylic acid and their interaction on visual score of Cortaderia selloana plants during 2018/2019 season.

S = Salinity levels / SA = Salicylic acid levels

Means having the same letter are not significantly differed at 0.05 level of probability according to Duncan's Multiple Range Test (Duncan, 1955).

enough to cause salt damage to cortaderia grass.

\section{Flowers parameters:}

Referring to the effect of salinity, data in Table (3) demonstrated that increasing salinity level indicated early flowering. Plants treated with salinity at 10,000 ppm were the earliest in flowering, but they had the lowest number of inflorescences/plant and the smallest inflorescence diameter. The highest values of flower parameters were obtained in plants irrigated with tap water
(399.67 and 414.83 days for number of days till flowering, 9.90 and 10.79 for number of inflorescences/plant and 15.74 and $17.22 \mathrm{~cm}$ for inflorescence diameter in both seasons, respectively.

Concerning the effect of SA application, data in Table (3) indicated that the different rates of SA influenced significantly the abovementioned flowering traits, compared to untreated plants in both seasons. The longest period of vegetative growth (378.25 and 392.17 days) until flowering, the highest number of inflorescences (9.54 and 9.73) and 
Table 3. Effect of saline water, salicylic acid and their interaction on number of days till flowering, number of inflorescences/plant and inflorescence diameter of Cortaderia selloana plants during 2017/2018 and 2018/2019 seasons.

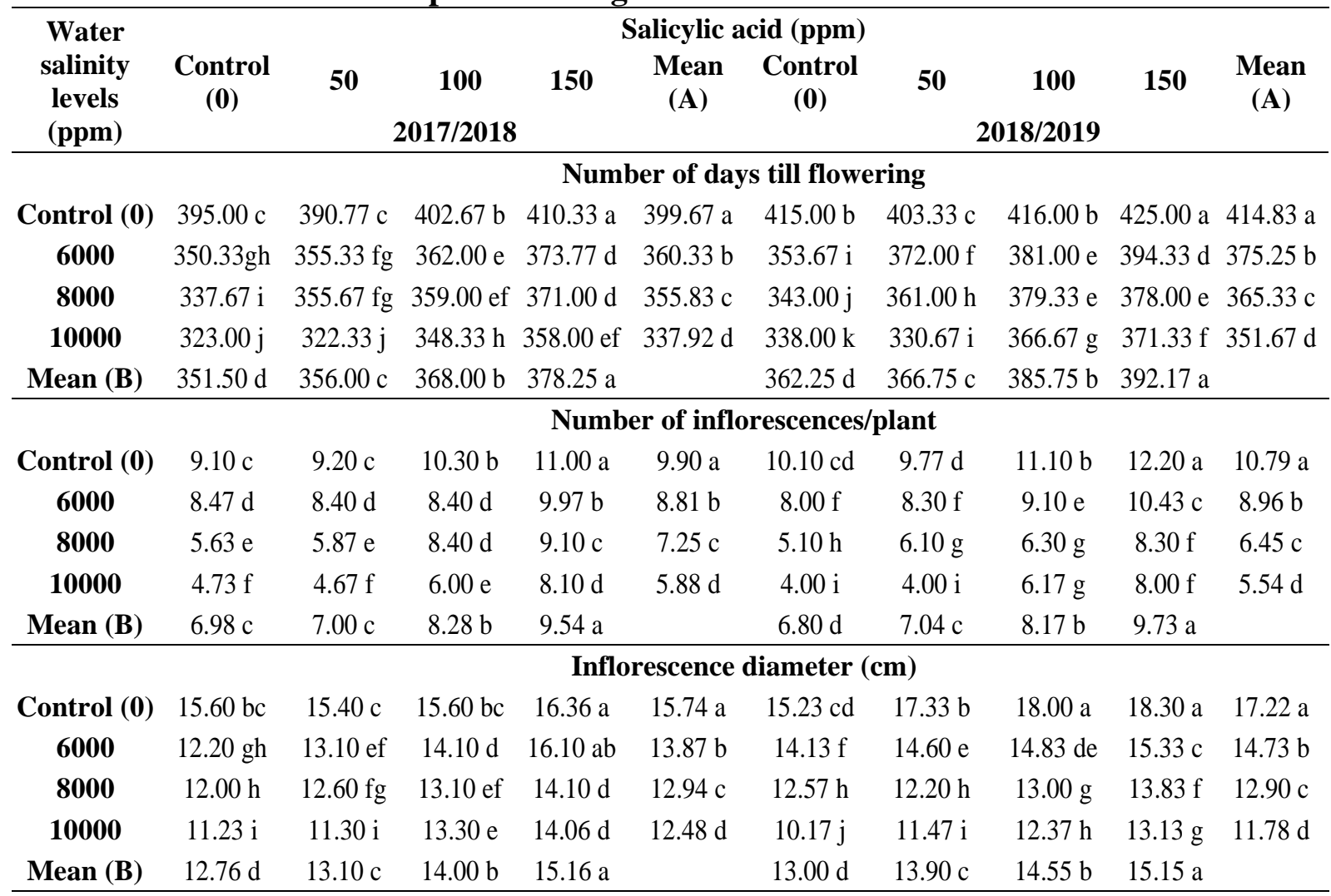

Means having the same letter are not significantly differed at 0.05 level of probability according to Duncan's Multiple Range Test (Duncan, 1955).

the longest inflorescences diameter (15.16 and $15.15 \mathrm{~cm}$ ), in both seasons respectively, were obtained with the application of SA at 150 ppm.

Regarding the interaction effect (Table, 3) the data show that increasing SA concentration could alleviate the adverse effect of water salinity, as the plants treated with 0 salinity and SA at $150 \mathrm{ppm}$ recorded the highest values (410.33 and 425.00 days for number of days till flowering, 11.00 and 12.2 for number of inflorescences/plant and 16.36 and $18.30 \mathrm{~cm}$ for the inflorescence diameter in both seasons, respectively).

As for irrigation with saline water data in Table (4) show that, there was a reduction in spike length and spike weight with increasing salt concentration. The shortest spikes (1.45 and $1.64 \mathrm{~m})$ and the lowest spike weight (116.2 and $117.1 \mathrm{~g}$ ) in both seasons, respectively, were recorded in plants that received $10000 \mathrm{ppm}$, whereas the greatest values $(2.33$ and $2.41 \mathrm{~m})$ for spike length and (181.4 and $178.8 \mathrm{~g}$ ) for spike weight in the $1^{\text {st }}$ and $2^{\text {nd }}$ seasons, respectively) were found in plants irrigated with tap water.

The same data in Table (4) showed the same trend of SA foliar application. Plants treated with increasing doses of SA showed a steady increase in both spike length and weight, the greatest values were 1.99 and $2.15 \mathrm{~m}$ and 160.8 and $168.1 \mathrm{~g}$ in both seasons, respectively.

Regarding the effect of the interaction between salinity and SA application, the highest values were 2.47 and $2.53 \mathrm{~m}$ for spike length and 200.8 and $206.4 \mathrm{~g}$ for spike weight in both seasons, respectively, for plants received non-saline water and SA at $150 \mathrm{ppm}$. 
Table 4. Effect of saline water, salicylic acid and their interaction on spike length and spike weight of Cortaderia selloana plants during 2017/2018 and 2018/2019 seasons.

\begin{tabular}{|c|c|c|c|c|c|c|c|c|c|c|}
\hline \multirow{3}{*}{$\begin{array}{c}\text { Water } \\
\text { salinity } \\
\text { levels } \\
\text { (ppm) }\end{array}$} & \multicolumn{10}{|c|}{ Salicylic acid (ppm) } \\
\hline & $\begin{array}{c}\text { Control } \\
\text { (0) }\end{array}$ & 50 & 100 & 150 & $\begin{array}{l}\text { Mean } \\
\text { (A) }\end{array}$ & $\begin{array}{c}\text { Control } \\
\text { (0) }\end{array}$ & 50 & 100 & 150 & $\begin{array}{l}\text { Mean } \\
\text { (A) }\end{array}$ \\
\hline & \multicolumn{6}{|c|}{ 2017/2018 } & \multicolumn{3}{|c|}{ 2018/2019 } & \\
\hline & \multicolumn{10}{|c|}{ Spike length (m) } \\
\hline Control (0) & $2.23 \mathrm{c}$ & 2.22 c & $2.39 \mathrm{~b}$ & 2.47 a & $2.33 \mathrm{a}$ & $2.31 \mathrm{~d}$ & $2.36 \mathrm{c}$ & $2.44 \mathrm{~b}$ & 2.53 a & $2.41 \mathrm{a}$ \\
\hline 6000 & $1.61 \mathrm{hi}$ & $1.66 \mathrm{~g}$ & $2.01 \mathrm{e}$ & $2.06 \mathrm{~d}$ & $1.83 \mathrm{~b}$ & $1.64 \mathrm{j}$ & $1.83 \mathrm{~h}$ & $2.07 \mathrm{f}$ & $2.27 \mathrm{e}$ & $1.95 \mathrm{~b}$ \\
\hline 8000 & $1.40 \mathrm{k}$ & $1.48 \mathrm{j}$ & $1.61 \mathrm{hi}$ & $1.82 \mathrm{f}$ & $1.58 \mathrm{c}$ & $1.56 \mathrm{k}$ & $1.55 \mathrm{k}$ & $1.79 \mathrm{~h}$ & $1.99 \mathrm{~g}$ & $1.72 \mathrm{c}$ \\
\hline 10000 & $1.24 \mathrm{~m}$ & $1.35 \mathrm{l}$ & $1.59 \mathrm{i}$ & $1.64 \mathrm{gh}$ & $1.45 \mathrm{~d}$ & $1.47 \mathrm{~m}$ & $1.52 \mathrm{l}$ & $1.73 \mathrm{i}$ & $1.83 \mathrm{~h}$ & $1.64 \mathrm{~d}$ \\
\hline \multirow[t]{2}{*}{ Mean (B) } & $1.62 \mathrm{~d}$ & $1.68 \mathrm{c}$ & $1.9 \mathrm{~b}$ & $1.99 \mathrm{a}$ & & $1.75 \mathrm{~d}$ & $1.81 \mathrm{c}$ & $2.01 \mathrm{~b}$ & $2.15 \mathrm{a}$ & \\
\hline & \multicolumn{10}{|c|}{ Spike weight (g) } \\
\hline Control (0) & $167.9 \mathrm{~d}$ & $173.0 \mathrm{c}$ & $184.0 \mathrm{~b}$ & 200.8 a & $181.4 \mathrm{a}$ & $162.0 \mathrm{e}$ & $165.7 \mathrm{~d}$ & $181.1 \mathrm{~b}$ & $206.4 \mathrm{a}$ & $178.8 \mathrm{a}$ \\
\hline 6000 & $135.8 \mathrm{gh}$ & $138.3 \mathrm{~g}$ & $151.3 \mathrm{e}$ & $165.5 \mathrm{~d}$ & $147.8 \mathrm{~b}$ & $141.1 \mathrm{hi}$ & $145.0 \mathrm{gh}$ & $147.7 \mathrm{~g}$ & $171.7 \mathrm{c}$ & $151.3 \mathrm{~b}$ \\
\hline 8000 & $111.2 \mathrm{ki}$ & $116.7 \mathrm{~g}$ & $132.4 \mathrm{hi}$ & $144.0 \mathrm{f}$ & $126.1 \mathrm{c}$ & $116.0 \mathrm{i}$ & $119.3 \mathrm{k}$ & $138.3 \mathrm{j}$ & $151.0 \mathrm{f}$ & 131.2 c \\
\hline 10000 & $107.9 \mathrm{~m}$ & 109.9 & $114.1 \mathrm{jk}$ & $132.8 \mathrm{i}$ & $116.2 \mathrm{~d}$ & $110.7 \mathrm{~m}$ & $104.6 \mathrm{n}$ & $110.0 \mathrm{~m}$ & 143.1h & $117.1 \mathrm{~d}$ \\
\hline Mean (B) & $130.7 \mathrm{~d}$ & $134.5 \mathrm{c}$ & $145.4 \mathrm{~b}$ & $160.8 \mathrm{a}$ & & $132.4 \mathrm{c}$ & 133.8 c & $144.3 \mathrm{~b}$ & $168.1 \mathrm{a}$ & \\
\hline
\end{tabular}

Means having the same letter are not significantly differed at 0.05 level of probability according to Duncan's Multiple Range Test (Duncan, 1955).

\section{Chemical compositions:}

For salinity effect Data in Table (5) refers to decreases in the contents of total carbohydrates and chlorophylls with increasing salinity concentrations, the highest values were recorded in plants watered with non-saline water giving 31.8\% D.W. for total carbohydrates and $1.44 \mathrm{mg} / \mathrm{g}$ F.W. for total chlorophylls.

Regarding SA application, the increase in SA doses caused an increment in total carbohydrates and chlorophylls, reaching the highest values (28.3 \% D.W and $1.23 \mathrm{mg} / \mathrm{g}$ F.W.) in plants sprayed with SA at $150 \mathrm{ppm}$. SA applications significantly mitigated the negative effect of salinity. The highest values for total carbohydrates and chlorophylls were $35.0 \%$ D.W. and 1.64 $\mathrm{mg} / \mathrm{g}$ F.W. respectively were recorded for plants irrigated with non-saline water and treated with SA at $150 \mathrm{ppm}$.

Data in Table (6) clear that increasing salt doses in irrigation water caused an increase in accumulation in the contents of proline, $\mathrm{Na}$ and $\mathrm{Cl}$. Salinity at 10,000 ppm resulted in the highest contents $(1.08 \mathrm{mg} / \mathrm{g}$ d.w. for proline, $4.85 \mathrm{mg} / \mathrm{g} \mathrm{d.w}$. for $\mathrm{Na}$ and $2.26 \mathrm{mg} / \mathrm{g} \mathrm{d} . \mathrm{w}$. for $\mathrm{Cl}$ ).

Data in Table (6) also show that foliar application with SA increased leaves proline content but decreased $\mathrm{Na}$ and $\mathrm{Cl}$ accumulation. The highest value was $(0.834$ $\mathrm{mg} / \mathrm{g} \mathrm{d}$.w. for proline) for plants received SA at $150 \mathrm{ppm}$, whenever the highest $\mathrm{Na}$ and $\mathrm{Cl}$ contents were 4.14 and $2.87 \mathrm{mg} / \mathrm{g}$ d.w., respectively for plants non-treated with SA.

Referring to the interaction between salinity and SA application data in Table (6) clear that SA increased proline content according to the increase in saline levels, reaching the maximum values $(1.300 \mathrm{mg} / \mathrm{g}$ d.w.) for plants received saline water at $10000 \mathrm{ppm}$ and SA at $150 \mathrm{ppm}$. On the other hand, SA application decreased $\mathrm{Na}$ and $\mathrm{Cl}$ accumulation under salt stress. The highest values were $5.15 \mathrm{mg} / \mathrm{g}$ d.w. for Na content and $3.49 \mathrm{mg} / \mathrm{g} \mathrm{d} . \mathrm{w}$. Cl content, for plants treated with saline water at $10000 \mathrm{ppm}$ and without SA application.

\section{DISCUSSION}

The previous results dealt with treating seedlings of Cortaderia seloana with 
Table 5. Effect of saline water, salicylic acid and their interaction on total carbohydrate and total chlorophyll on Cortaderia selloana plants during 2018/2019 season.

\begin{tabular}{ccccccccccc}
\hline $\begin{array}{c}\text { Water } \\
\text { salinity } \\
\text { levels (ppm) }\end{array}$ & $\begin{array}{c}\text { Control } \\
\mathbf{( 0 )}\end{array}$ & $\mathbf{5 0}$ & $\mathbf{1 0 0}$ & $\mathbf{1 5 0}$ & $\begin{array}{c}\text { Mean } \\
\mathbf{( A )}\end{array}$ & $\begin{array}{c}\text { Control } \\
\mathbf{( 0 )}\end{array}$ & $\mathbf{5 0}$ & $\mathbf{1 0 0}$ & $\mathbf{1 5 0}$ & $\begin{array}{c}\text { Mean } \\
\text { (A) }\end{array}$ \\
\hline \multicolumn{4}{c}{ Total carbohydrate $\mathbf{( \% )} \mathbf{~ d . w . ~}$} & \multicolumn{7}{c}{ Total chlorophyll (mg/g f.w.) } \\
Control (0) & $28.6 \mathrm{~d}$ & $29.9 \mathrm{c}$ & $33.8 \mathrm{~b}$ & $35.0 \mathrm{a}$ & $31.8 \mathrm{a}$ & $1.31 \mathrm{de}$ & $1.32 \mathrm{~d}$ & $1.48 \mathrm{~b}$ & $1.64 \mathrm{a}$ & $1.44 \mathrm{a}$ \\
$\mathbf{6 0 0 0}$ & $22.3 \mathrm{~g}$ & $22.0 \mathrm{~h}$ & $24.0 \mathrm{f}$ & $26.2 \mathrm{e}$ & $23.6 \mathrm{~b}$ & $1.03 \mathrm{f}$ & $1.03 \mathrm{f}$ & $1.29 \mathrm{e}$ & $1.36 \mathrm{c}$ & $1.18 \mathrm{~b}$ \\
$\mathbf{8 0 0 0}$ & $19.1 \mathrm{k}$ & $20.5 \mathrm{i}$ & $22.3 \mathrm{~g}$ & $26.0 \mathrm{e}$ & $22.0 \mathrm{c}$ & $0.91 \mathrm{~h}$ & $0.92 \mathrm{~h}$ & $0.93 \mathrm{~h}$ & $1.00 \mathrm{~g}$ & $1.94 \mathrm{c}$ \\
$\mathbf{1 0 0 0 0}$ & $19.2 \mathrm{jk}$ & $19.5 \mathrm{j}$ & $22.3 \mathrm{gh}$ & $26.0 \mathrm{e}$ & $21.7 \mathrm{~d}$ & $0.88 \mathrm{ij}$ & $0.87 \mathrm{j}$ & $0.90 \mathrm{hi}$ & $0.93 \mathrm{~h}$ & $0.90 \mathrm{~d}$ \\
$\mathbf{M e a n} \mathbf{( B )}$ & $22.3 \mathrm{~d}$ & $23.0 \mathrm{c}$ & $25.6 \mathrm{~b}$ & $28.3 \mathrm{a}$ & & $1.03 \mathrm{c}$ & $1.04 \mathrm{c}$ & $1.15 \mathrm{~b}$ & $1.23 \mathrm{a}$ \\
\hline
\end{tabular}

Means having the same letter are not significantly differed at 0.05 level of probability according to Duncan's Multiple Range Test (Duncan, 1955).

Table 6. Effect of saline water, salicylic acid and their interaction on proline, $\mathrm{Na}$ and $\mathrm{Cl}$ contents in leaves of Cortaderia selloana plants during 2018/2019 season.

\begin{tabular}{|c|c|c|c|c|c|}
\hline \multirow{2}{*}{$\begin{array}{c}\text { Water salinity } \\
\text { levels (ppm) }\end{array}$} & \multicolumn{5}{|c|}{ Salicylic acid (ppm) } \\
\hline & Control (0) & 50 & 100 & 150 & Mean (A) \\
\hline & \multicolumn{5}{|c|}{ Proline content (mg/g d.w) } \\
\hline Control (0) & $0.433 \mathrm{k}$ & $0.440 \mathrm{k}$ & $0.481 \mathrm{j}$ & $0.506 \mathrm{j}$ & $0.465 \mathrm{~d}$ \\
\hline 6000 & $0.581 \mathrm{i}$ & $0.580 \mathrm{i}$ & $0.614 \mathrm{~h}$ & $0.644 \mathrm{~g}$ & 0.605 c \\
\hline 8000 & $0.784 \mathrm{f}$ & $0.787 \mathrm{f}$ & $0.822 \mathrm{e}$ & $0.885 \mathrm{~d}$ & $0.820 \mathrm{~b}$ \\
\hline 10000 & $0.974 \mathrm{c}$ & 0.982 c & $1.077 \mathrm{~b}$ & $1.300 \mathrm{a}$ & $1.080 \mathrm{a}$ \\
\hline \multirow[t]{2}{*}{ Mean (B) } & $0.693 \mathrm{c}$ & $0.697 \mathrm{c}$ & $0.749 \mathrm{~b}$ & $0.834 \mathrm{a}$ & \\
\hline & \multicolumn{5}{|c|}{ Na (mg /g d.w.) } \\
\hline Control (0) & $2.84 \mathrm{k}$ & $2.86 \mathrm{k}$ & $2.60 \mathrm{l}$ & $2.40 \mathrm{~m}$ & $2.68 \mathrm{~d}$ \\
\hline 6000 & $3.93 \mathrm{~h}$ & $3.88 \mathrm{~h}$ & $3.41 \mathrm{i}$ & $3.30 \mathrm{j}$ & $3.63 \mathrm{c}$ \\
\hline 8000 & $4.62 \mathrm{~d}$ & $4.33 \mathrm{f}$ & $4.25 \mathrm{~g}$ & $3.94 \mathrm{~h}$ & $4.28 \mathrm{~b}$ \\
\hline 10000 & $5.15 \mathrm{a}$ & $4.98 \mathrm{~b}$ & 4.73 c & $4.54 \mathrm{e}$ & $4.85 \mathrm{a}$ \\
\hline \multirow[t]{2}{*}{ Mean (B) } & $4.14 \mathrm{a}$ & $4.01 \mathrm{~b}$ & $3.75 \mathrm{c}$ & $3.55 \mathrm{c}$ & \\
\hline & \multicolumn{5}{|c|}{ Cl (mg /g d.w.) } \\
\hline Control (0) & $2.09 \mathrm{~h}$ & $1.92 \mathrm{i}$ & $1.80 \mathrm{j}$ & $1.70 \mathrm{j}$ & $1.88 \mathrm{~d}$ \\
\hline 6000 & $2.85 \mathrm{~d}$ & 2.67 ef & $2.31 \mathrm{~g}$ & $2.25 \mathrm{~g}$ & $2.52 \mathrm{c}$ \\
\hline 8000 & 3.04 bc & $2.95 \mathrm{c}$ & $2.75 \mathrm{e}$ & $2.62 \mathrm{f}$ & $2.84 \mathrm{~b}$ \\
\hline 10000 & $3.49 \mathrm{a}$ & $3.44 \mathrm{a}$ & $3.13 \mathrm{~b}$ & $2.98 \mathrm{c}$ & $2.26 \mathrm{a}$ \\
\hline Mean (B) & $2.87 \mathrm{a}$ & $2.74 \mathrm{~b}$ & $2.50 \mathrm{c}$ & $2.39 \mathrm{~d}$ & \\
\hline
\end{tabular}

Means having the same letter are not significantly differed at 0.05 level of probability according to Duncan's Multiple Range Test (Duncan, 1955).

salicylic acid grown under salinity stress of irrigation water. Salinity had significant negative effects on growth and physiological traits. Growth parameters and chemical composition improved upon using salicylic acid, as foliar application of SA decreased the negative effects of salinity stress. These results were in accordance with the findings of a lot of other researchers demonstrated in the following discussion: Handreck and Black. (2002) declared that salinity may have a negative effect on water absorption and biochemical processes, such as $\mathrm{N}$ and $\mathrm{CO}_{2}$ assimilation and protein biosynthesis or may accumulate high concentration of some highly hydrophilic ions (e.g. Na or borate) and toxic ones such as $\mathrm{Cl}$ in plant tissues. Our results may be attributed to a decrease in cell size at constant cell number caused by salinity. Netondo et al. (2004) and Zhao et al. (2007) stated that salinity may inhibit chlorophyll synthesis and/or accelerate its 
degradation. In this regard, Baraga et al. (2009) reported that salinity inhibited cell division and enlargement, consequently suppression of plant growth. Szepsi et al. (2005) and Karlidage et al. (2009) stated that the positive effect of SA could be related to an increased $\mathrm{CO}_{2}$ assimilation and photosynthetic rate and increased mineral uptake by the stressed plant under SA treatment.

Hussain et al. (2010) reported that spraying Pennisetum glaucum with salicylic acid had increased the fresh and dry weights of shoot and root growth that decreased due to salinity. Bayat et al. (2012) showed that foliar applications of SA resulted in greater shoot, root and total dry weights, plant height, flower number/plant and flower diameter of calendula under salt stress. Pacheco et al. (2013) showed that SA application increase number of leaves/plant, leaf dry mass, leaf chlorophyll content and number of inflorescences of Calendula officinalis. Azimi et al. (2014) demonstrated that SA foliar applications at (50, 100 and $200 \mathrm{mg} / \mathrm{l}$ ) on bluegrass sport mixture increased the vegetative growth and chlorophyll (a, b and total) content.

Ali and Attia (2015) on Rosmarinus officinalis reported that SA application increased the shoot growth under salt stress. Manzoor et al. (2015) found that salicylic acid significantly affected shoot and root dry matter of some cvs. of maize under salt stress. Foliar application of SA significantly increased proline and chlorophyll contents. Liu et al. (2016) on ten ornamental plants, stated that some plants showed difference in the degree of salinity tolerance, as Chaenomeles speciosa and Diervilla rivularis grown in EC 5 (3200 ppm) conditions had severe salt foliar damage, whereas those in EC 10 (6400) were dead. Hibiscus syriacus performed well in EC 5 (3200 ppm) treatment with a shoot dry weight reduction of $26 \%$, but those grown under EC 10 (6400) had severe foliar salt damage. Hydrangea macrophylla was the most salt tolerant with minor foliar salt damage. It had the highest shoot sodium $\mathrm{Na}$ and $\mathrm{Cl}$ concentrations, indicating that $H$. macrophylla plants adapted to elevated salinity by tolerating high $\mathrm{Na}$ and $\mathrm{Cl}$ levels in leaf tissue. Salachna and Piechocki (2016) remarked that shoot, root and flower parameters in plants treated with salinity decreased in a concentration dependent manner. They also showed the negative effects of salinity stress on morphological traits and flowering of plants.

Ahmed (2017) on Hibiscus rosa-sinensis found that all shoot and root growth traits, flower diameter and flower fresh and dry weights decreased gradually with increasing rate of salinity in irrigation water. Moreover, increasing salinity levels caused an increase in $\mathrm{Na}, \mathrm{Cl}$ and proline content. Arghavani et al. (2017) on Kentucky bluegrass found that SA application ameliorated adverse effects of salinity on shoot and root dry weights, leaf chlorophyll content, sodium and leaf proline contents. Ma et al. (2017) on Dianthus superbus found that SA application increased fresh weight and biomass compared with non SA treatments under salt stress.

Sun and Palmer (2018) demonstrated that seven ornamental grass or grass-like species had a very strong tolerance to the salinity levels (saline solutions at an EC of 5.0 or $10.0 \mathrm{dS} / \mathrm{m}=3200$ or $6400 \mathrm{ppm}$ ) used in the 4-month experiment, although shoot and root dry weights, number of tillers and number of inflorescences were inhibited as a result of saline irrigation.

On some similar ornamental grasses, Wang et al. (2019) stated that Eragrostis spectabilis, Miscanthus sinensis, Panicum virgatum and Schizachyrium scoparium showed a very strong salt tolerance with an acceptable visual quality, they also reported that plant height, leaf area, number of inflorescences and tillers of four tested ornamental grasses decreased to some extent, and high $\mathrm{Na}^{+}$and $\mathrm{Cl}^{-}$accumulated in the leaf tissue as a result of the salt-induced water deficit. However, all ornamental grass species still had a good visual quality. 
Sabzmeydani et al. (2020) on Poa pratensis stated that the increase in salinity resulted in impaired shoot and root weight, plant height, number of tillers in addition to an accumulation of $\mathrm{Cl}$ and $\mathrm{Na}$ in leaves. In contrast, SA mitigated these harmful effects of salinity. SA application increased shoot and root fresh weight and number of tillers in salinity-affected plants.

\section{REFERENCES}

Ahmed, M.A. (2017). Effect of salinity $\left(\mathrm{NaCl}+\mathrm{CaCl}_{2}\right)$ and some soil additions on growth, flowering and chemical composition of rose of china (Hibiscus rosa-sinensis L.) plant. Middle East Journal of Agriculture Research, 6(2):302-314.

Ali, H. and Attia, M. (2015). Response of salt rosemary plants to antistress agents. Scientific Journal of Flowers and Ornamental Plants, 2(3):249-264.

Al-Whaibi, M.H.L.; Siddiqui, M.H. and Basalah, M.O. (2012). Salicylic acid and calcium-induced protection of wheat against salinity. Protoplasma, 249(3):769-778.

Arghavani, M.; Savadkoohi, S. and Mortazavi, S. (2017). Salinity tolerance of kentucky bluegrass as affected by salicylic acid. Journal of Ornamental Plants, 7(4):237-245.

Azimi, M.H.; Bakhteyari, F.; Khalaj, M.A. and Basaki, T. (2014). Influence of cycocel and salicylic acid on morphological and physiological characteristics of bluegrass sport mixture. Agricultural Communications, 2(1):4348.

Baraga, L.E.; Da Sousa, M.P. and Almeida, T.A. (2009). Enterolobium schomburgkii Benth. seed germination under saline stress and polyamine application. Revista Braz. Plantas Med., 11(1):1516-1527.

Bates, L.S.; Walden, R.P. and Teare, T.D. (1973). Rapid determination of free proline for water stress studies. Plant and Soil, 39:305-307.
Bayat, H.; Alirezaie, M. and Neamati, H. (2012). Impact of exogenous salicylic acid on growth and ornamental characteristics of calendula (Calendula officinalis L.) under salinity stress. Journal of Stress Physiology and Biochemistry, 8(1):258-267.

Bian, A. and Pan, D. (2018). Effect of salt stress on growth and inorganic ion distribution in Narcissus tazzeta L. var. chinensis seedlings. HortScience, 53(8):1152-1156.

Dempsey, D.A. and Klessig, D.F. (2017). How does the multifaceted plant hormone salicylic acid combat disease in plants and are similar mechanisms utilized in humans?. BMC Biology, 15(23):1-11. https://doi.org/10. 1186/s12915-017-0364-8

Dubois, M.; Gilles, K.A.; Hamilton, J.K.; Rebers, P.T. and Smith, F. (1956). Colorimetric method for determination of sugars and related substances. Analytical Chemistry, 28(3):350 356.

Duncan, D.B. (1955). Multiple range and multiple $\mathrm{F}$ test. Journal of Biometrics, 11:1-42.

El-Fouly, A.S.; Abdel-Sattar, M.M. and Shahin, S.M. (2015). Effect of different salinity levels, $\mathrm{PP}_{333}$ treatments and their interaction on growth, flowering, bulbs productivity and chemical composition of Iris tingitana cv. Wedgewood. J. Agric. Res., Kafr ElSheikh Univ., 41(1): 347-369.

El-Tayeb, M.A. (2005). Response of barley grain to the interactive effect of salinity and salicylic acid. Plant Growth Regul, 45 (3):215-224.

Gomez, K.A. and Gomez, A.A. (1984). Statistical Procedures for Agricultural Research. John Wiley \& Sons, New York, USA, $680 \mathrm{p}$.

Handreck, K. and Black, N. (2002). Growing Media for Ornamental Plants and Turf, $3^{\text {rd }}$ ed. Univ. of New South Wales Press Ltd., Sydney, Australia, 542 p. 
Hassan, A. and Abd El-Azeim, M. (2019). Gibberellic acid usage relieving salinity adverse effects on growth, flowering and bulb production of tuberose plants (Polianthes tuberosa, L.). Journal of Plant Production, 10(12):1051-1058.

Hoang, H.L.; De Guzman, C.C.; Cadiz, N.M.; Hoand, T.T.; Tran, D.H. and Rehman, H. (2020). Salicylic acid and calcium signaling induce physiological and phytochemical changes to improve salinity tolerance in red amaranth (Amaranthus tricolor L.). J. Soil Sci. Plant Nutr. https://doi.org/10.1007/ s42729-020-00248-4

Hussain, K.; Nawaz, K.; Majeed, A.; Khan, F.; Lin, F.; Ghani, A.; Raza, G.; Afghan, S.; Zia-ul-Hussnain, S.; Ali, K. and Shahazad, A. (2010). Alleviation of salinity effects by exogenous applications of salicylic acid in pearl millet (Pennisetum glaucum (L.) R. Br.) seedlings. African Journal of Biotechnology, 9(50):8602-8607.

Jackson, M.H. (1973). Soil Chemical Analysis. Prentice hall of India private Ltd M-97, Delhi, India, 498 p.

Karlidag, H.; Yildirim, E. and Turan, M. (2009). Salicylic acid ameliorates the adverse effect of salt stress on strawberry. Sci. Agric., 66(2):180-187.

Kudla, J.; Becker, D.; Grill, E.; Hedrich, R.; Hippler, M.; Kummer, U.; Parniske, M.; Romeis, T. and Schumacher, K. (2018). Advances and current challenges in calcium signaling. New Phytol., 218(2):414 431.

Leite, T.S.; De Freitas, R.M.; Nogueira, N.W.; Leite, M.S. and Pinto, J.R. (2017). The use of saline aquaculature effluent for production of Enterolobium contortisiliquum seedlings. Environ. Sci. \& Poll. Res., 24(23):19306-19312.

Liu, W.; Zhang, Y.; Yuan, X.; Xuan, Y.; Gao, Y. and Yan, Y. (2016). Exogenous salicylic acid improves salinity tolerance of Nitraria tangutorum. Russian Journal of Plant Physiology, 63(1):132-142.

Ma, X.; Zheng, J.; Zhang, X.; Hu, Q. and Qian, R. (2017). Salicylic acid alleviates the adverse effects of salt stress on Dianthus superbus (Caryophyllaceae) by activating photosynthesis, protecting morphological structure, and enhancing the antioxidant system. Frontiers in Plant Science, 8, 600.

Manzoor, K.; Ilyas, N.; Batool, N.; Ahmad, B. and Arshad, M. (2015). Effect of salicylic acid on the growth and physiological characteristics of maize under stress conditions. Journal of Chemical Society of Pakistan, 37(3):588593.

MSTAT Development Team (1989). MSTAT user's guide: a microcomputer program for the design management and analysis of agronomic research experiments. Michigan State University, East Lansing, USA.

Netondo, G.W.; Onyango, J.C. and Beck, E. (2004). Sorghum and salinity: II. Gas exchange and chlorophyll fluorescence of sorghum under salt stress. Crop Sci., 44(3):806-811.

Oakes, A.J. (1990). Ornamental Grasses and Grasslike Plants. Van Nostrand Reinhold, New York, USA, 614 pp.

Oliveira, F.I.; De Medeiros, W.J.; De Lacerda, C.F. and Neves, A.L. (2017). Saline water irrigation managements on growth of ornamental plants. Rev. Braz. Eng. Agric. Ambient., 21(11): 739-745.

Pacheco, A.; Cabral, C. and Aelman, E. (2013). Salicylic acid-induced changes to growth, flowering and flavonoids production in marigold plants. Journal of medicinal plant Research, 7(42):31583163.

Sabzmeydani, E.; Sedaghathoor, S. and Hashemabadi, D. (2020). Progesterone and salicylic acid elevate tolerance of Poa pratensis to salinity stress. Russian 
Journal of Plant Physiology, 67(2):285293.

Salachna, P. and Piechocki, R. (2016). Effects of sodium chloride on growth and mineral nutrition of purpletop vervain. Journal of Ecological Engineering, 17(2):148-152.

Sun, Y. and Palmer, A. (2018). Responses of ornamental grass and grasslike plants to saline water irrigation. HortTechnology, 28:799-806.

Sun, Y.; Niu, G. and Perez C. (2015). Relative salt tolerance of seven Texas superstar perennials. HortScience, 50(10):1562-1566.

Szepesi, A.; Csiszar, J.; Bajkan, S.; Gemes, K.; Horvath, F.; Erdei, L.; Deer, A.K.; Simon, M.L. and Tari, I. (2005). Role of salicylic acid pretreatment on the acclimation of tomato plants to salt- and osmotic stress. Acta. Biol. Szeg., 49(1):123-125.
Tissa, S.; Darren, T.; Eric, B. and Kingsley, D. (2000). Acetyl salicylic acid (aspirin) and salicylic acid induce multiple stress tolerance in bean and tomato plants. Plant Growth Regul., 30 (2):157-161.

Wang, Y.; Sun, Y.; Niu, G.; Deng, C.; Wang, Y. and Gardea-Torresdey, J. (2019). Growth, gas exchange, and mineral nutrients of ornamental grasses irrigated with saline water. HortScience, 54(10):1840-1846.

Wellburn, A.R. and Lichtenthaler, H. (1984). Formulae and program to determine total carotenoids and chlorophylls $\mathrm{a}$ and $\mathrm{b}$ of leaf extracts in different solvents. Adv. Agri. Biotechn., 2(1):9-12.

Zhao, G.Q.; Ma, B.L. and Ren, C.Z. (2007). Growth, gas exchange, chlorophyll fluorescence, and ion content of naked oat in response to salinity. Crop Sci., 47(1):123-131.

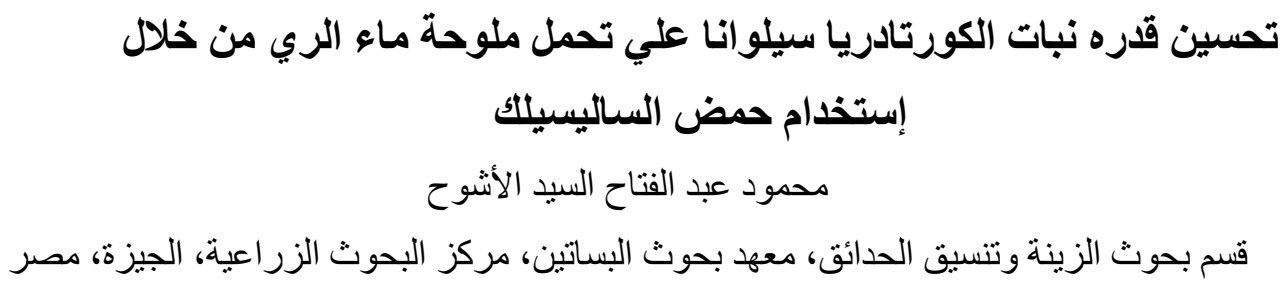



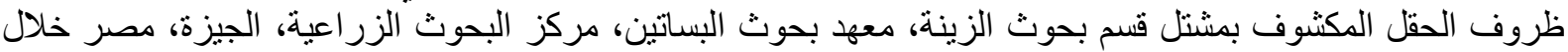

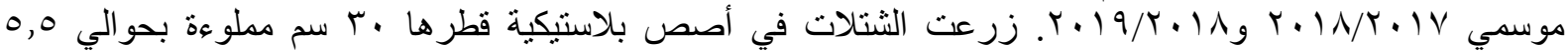

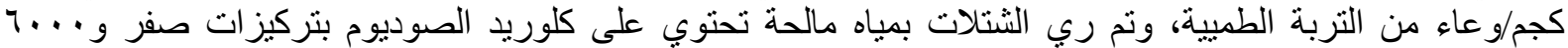

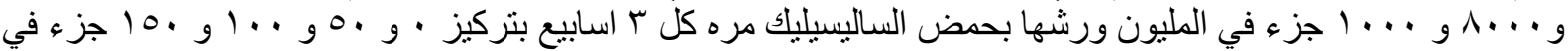



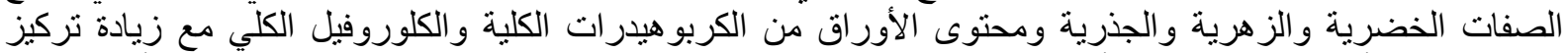

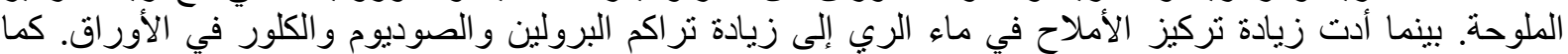

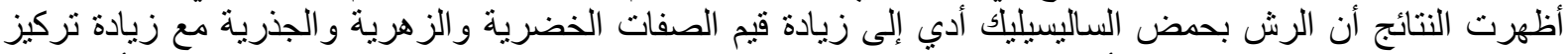

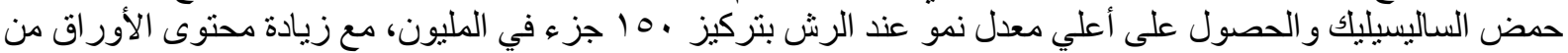

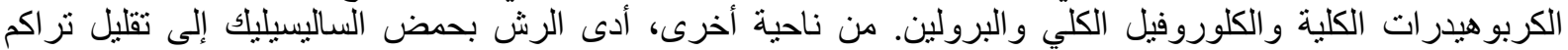

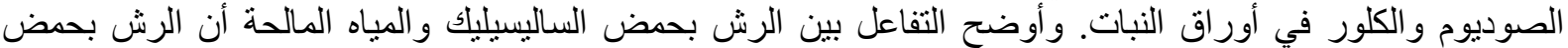



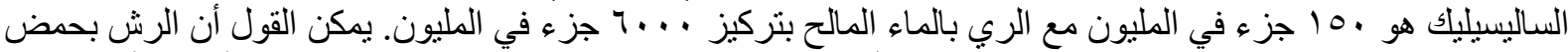

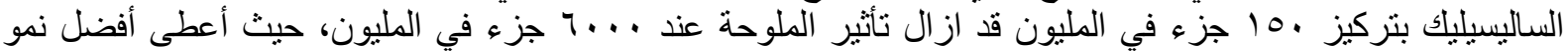

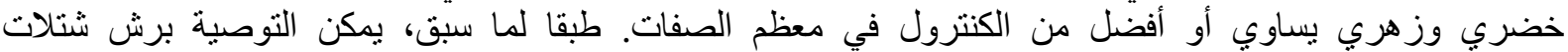
Cortaderia selloana . 10. 